\title{
EWA SMOLEŃ
}

\section{Selected dietary habits of academic youth - students of Sanok high school}

\begin{abstract}
Introduction. Nutrition and diet are significant elements of health behaviour determining health status. Dietary habits result from social and economical conditions, which are responsible for specific health behaviour and the choice of a particular dietary model. Normal health status is determined by 24-hour meal plan as well as quality and quantity of nutritional components. The Committee on Human Nutrition of Polish Academy of Science, the Institute of Food and Nutrition, and Polish Society of Nutritional Sciences elaborated dietary recommendations for general population in Poland. When acting according to these guidelines, the organism is provided with all necessary nutritional components and the most frequent dietary mistakes of young Poles can be avoided.

Aim. Assessment of selected dietary habits of Grodek State Vocational High School in Sanok.

Material and methods. The study included 194 students of Higher State Vocational School. The participation in the study was voluntary and anonymous. A survey questionnaire, developed by the author, assessed 24-hour plan of meals and their quality as well as students' compliance with the principles of rational nutrition. Outcomes were analysed statistically using the chi-square test of independence.

Conclusions. The majority of respondents had at least three or four meals a day. More than half of the study group declared they had breakfast every day, and for most students it was the most important meal in their daily menu. Every second student living in the city or country had a two-course dinner whereas significantly smaller number of rural inhabitants participating in the study declared so. The most frequent dietary mistakes included consuming sweets between meals, frequent drinking of coffee, excessive consumption of meat, especially by men, and a rare consumption of fish.
\end{abstract}

Results. The determination of dietary mistakes among students allows correcting them by adequate preventive actions.

Keywords: dietary habits, dietary mistakes, students.

DOI: $10.12923 / \mathrm{j} .0044-2011 / 123-3 / a .08$

\section{INTRODUCTION}

A way of nutrition is a crucial element of health behaviour, shaping the medical condition of the individual and societies. Social and economic factors condition the dietary style, i.e. education, the domicile, the income level and the tradition [1]. Significant role in determining the demand for appropriate quantitative composition and quality of meals is exerted by sex and an age. This conditioning decides on accepting specific health behaviour and choice of the preferred model of dieting which is shaped in the period of adolescence, and definitively matures in the period of adulthood. The influence of mass media and close environment have their impact on choice of the dietary style while studying not always promoting healthy style, but being accepted in a peer group. A twenty-four hour plan of meals and nutritients consumption is important for the correct medical condition [2]. They are precisely described by nutritional standards, taking into account the daily demand for nutritients and the energy for the person dependent on the age, sex, the physiological state, the physical activity and living conditions and lifestyle. They guarantee normal physical and psychological development process and the health for every man. Norms of the caloric requirements in Poland take into account nineteen groups of the population including the age, sex and the physiological state and the physical activity and the due body mass [3].

Fundamentals of dieting for the Polish population were developed in 1998 by the The Committee on Human Nutrition of Polish Academy of Science, the Institute of Food and Nutrition, and Polish Society of Nutritional Sciences. Fundamental rule of healthy dieting is optimal plan of meals in a day, recommending daily consumption of four to five meals, with the compulsory breakfast. Food of the plant and animal origin should be included in a daily menu. Nutrients which one should consumer every day are raw or cooked fruit and vegetables and cereals. Two - and even three times in a day one should consume milk and its low-fat products. According to recommendations cutting down on consuming meat and its products to only two or of three times during the week is important. Supplementing the protein source should be fish and pulses. In the diet, one should reduce the amount 
of fat to the minimum, especially animal, fat and best replace it with vegetable oils and olive oil. In healthy dieting limiting consuming the salt and the resignation from so-called 'salting' some dishes is another recommendation. Also reducing consuming monosaccharides is significant. Fruit and vegetables as an addition to every meal should constitute the source of carbohydrates [4].

Frequent mistakes in dieting of Poles are irregular consuming of meals, particularly of breakfast. Poles consume too little vegetables and fruit which frequently leads to deficiency of vitamins and minerals. Low supply of calcium in the diet is caused by unsatisfactory daily consumption of milk and its products. Poles consume a lot of meat and meat products, but too little fish, especially sea fish. Also an excessive consumption of simple carbohydrates and animal fats is a problem in dieting of Poles [5].

\section{AIM}

The purpose of research was an evaluation of chosen health behaviour in dieting of students Grodek State Vocational High School in Sanok taking into account dieting mistakes.

\section{MATERIAL AND METHODS}

The research was conducted in 2010 amongst 194 students of Grodek State Vocational High School in Sanok, in courses of pedagogy, nursing and farming. The participation in examination was voluntary and anonymous. A survey questionnaire, developed by the author was applied. Questions of open and closed character concerned the regularity of consuming meals in the daily menu, their quantitative and qualitative composition and of the habit of consuming food between meals. Collected data were subjected to statistical analysis applying $\mathrm{ch}^{2}$ Pearson's independence test. The following significance levels were accepted: $p<0.0001$ very high statistical relation, $\mathrm{p}<0.01$ highly essential statistical relation, $p<0.1$ weak statistical relation, $p>0.5$ lack of the essential statistical relation.

\section{RESULTS}

Analysis of results showed that every seventh student had eaten five meals a day, and every fourth - four meals a day (Table 1). Similar percentage of examined women $(80.9 \%)$ and men $(67.7 \%)$ regarded the breakfast as the most important meal in the daily menu. For the $15.4 \%$ of women and definitely the largest group of men $(25.8 \%)$, dinner was a basic meal, however for the $6.5 \%$ of men and almost for the half of women $(3.7 \%)$ the main meal was supper $(\mathrm{p}<0.5)$.

It is worthwhile to emphasize that breakfast was the most important meal in the daily menu both for the $81.4 \%$ of city dwellers and the $77.6 \%$ of the rural dwellers. Definitely a smaller percentage of rural dwellers (19.4\%) and city dwellers (11.9\%) regarded dinner most important meal in the daily plan of meals. However only the $3.0 \%$ of students living in the rural area and $6.8 \%$ of those living in a city recognised supper as such.

Similar percentage of students living in a city $(66.1 \%)$ and in the country $(66.4 \%)$ had breakfast every day. Generally speaking, $3.8 \%$ of country dwellers and half fewer of city
TABLE 1. Number of meals in a daily menu of students with regard to their domicile.

\begin{tabular}{|c|c|c|c|c|c|c|}
\hline \multirow{3}{*}{$\begin{array}{l}\text { Number } \\
\text { of meals }\end{array}$} & \multicolumn{4}{|c|}{ The domicile } & \multirow{2}{*}{\multicolumn{2}{|c|}{ In total }} \\
\hline & \multicolumn{2}{|c|}{ City } & \multicolumn{2}{|c|}{ Country } & & \\
\hline & $\mathrm{N}$ & $\%$ & $\mathrm{~N}$ & $\%$ & $\mathrm{~N}$ & $\%$ \\
\hline One & 2 & $3.4 \%$ & 7 & $5.2 \%$ & 9 & $4.7 \%$ \\
\hline Two & 4 & $6.8 \%$ & 14 & $10.4 \%$ & 18 & $9.3 \%$ \\
\hline Three & 18 & $30.5 \%$ & 43 & $32.1 \%$ & 61 & $31.6 \%$ \\
\hline Four & 22 & $37.3 \%$ & 54 & $40.3 \%$ & 76 & $39.4 \%$ \\
\hline Five & 8 & $13.6 \%$ & 15 & $11.2 \%$ & 23 & $11.9 \%$ \\
\hline \multicolumn{2}{|c|}{ Value $=9.075$} & \multicolumn{2}{|c|}{$\mathrm{df}=5$} & \multicolumn{2}{|c|}{$\mathrm{p}=0.106$} & \\
\hline
\end{tabular}

dwellers $-1.7 \%(\mathrm{p}<0.5)$ didn't eat breakfast at all. City dwellers $(30.5 \%)$ and only $22.1 \%$ of rural dwellers had breakfast a few times a week. Dinner consisting of two dishes was consumed by $48.3 \%$ of city dwellers and only $27.9 \%$ of country dwellers $(p<0.0001)$. The substantial amount of men comparing to women had dinner consisting of two dishes every day (Table 2).

TABLE 2. The frequency of consuming dinner by the students.

\begin{tabular}{lcccc}
\hline \multirow{2}{*}{\multicolumn{1}{c}{ Frequency }} & \multicolumn{4}{c}{ Sex } \\
\cline { 2 - 6 } & \multicolumn{2}{c}{ Women } & \multicolumn{2}{c}{ Men } \\
\cline { 2 - 6 } & $\%$ & $\mathrm{~N}$ & $\%$ & $\mathrm{~N}$ \\
\hline Every day & $33.8 \%$ & 53 & $36.7 \%$ & 11 \\
\hline Only on Saturdays and Sundays & $44.6 \%$ & 70 & $26.7 \%$ & 8 \\
\hline Never & $11.5 \%$ & 18 & $6.7 \%$ & 2 \\
\hline Others & $10.2 \%$ & 16 & $30.0 \%$ & 9 \\
\hline \multicolumn{2}{c}{ Value=9.936 } & \multicolumn{2}{c}{$\mathrm{df}=3$} & $\mathrm{p}=0.019$ \\
\hline
\end{tabular}

Over half of the examined men (58.1\%) and much smaller number of women $(49.7 \%)$ overlooked the time of consuming the last meal. Similar percentage of women $(32.5 \%)$ and men $(32.3 \%)$ ate supper not later than 2 hours before sleep ( $>0.5$ ). An hour before sleep 9.6\% of women in comparison to $6.5 \%$ men had their supper. No man and only $2.5 \%$ of women ate supper directly before sleep. Substantial number of city dwellers (56.1\%) compared with those living in the country $(48.9 \%)$ overlooked the time of consuming the last meal $-36.6 \%$ of those living in the country and $22.8 \%$ of city dwellers had the last meal two hours before sleep. Similar percentage of city dwellers $(8.8 \%)$ and rural dwellers $(9.2 \%)$ had supper scarcely an hour before sleep $(\mathrm{p}<0.5)$. Supper was most abundant meal in a day decidedly more often for men $(74.2 \%)$ comparing to women (51.2\%) $(\mathrm{p}<0.05$, chi square $=5.54 \mathrm{df}=1)$ (Figure 1$)$.

Every day, a larger percentage of men ate pork (10.0\%) as compared to only $1.2 \%$ of women $(p<0.0001)$. Men decidedly more than women had pork (Table 3 ). Rural dwellers more frequently resigned from pork $(21.1 \%)$ as compared to city dwellers (15.3\%). None city dweller declared everyday consuming of pork, but everyday consumption of pork was declared by $3.8 \%$ of country dwellers (Table $3)$. Men $(10.0 \%)$ more often than women $(0.6 \%)$ declared everydayconsuming ofbeef $(p<0.01)$. Beefwasconsumedonce a week by two times as many men as compared to women (Table 3). However barely once a week beef was consumed by every fourth dweller of the city and every fifth dweller 


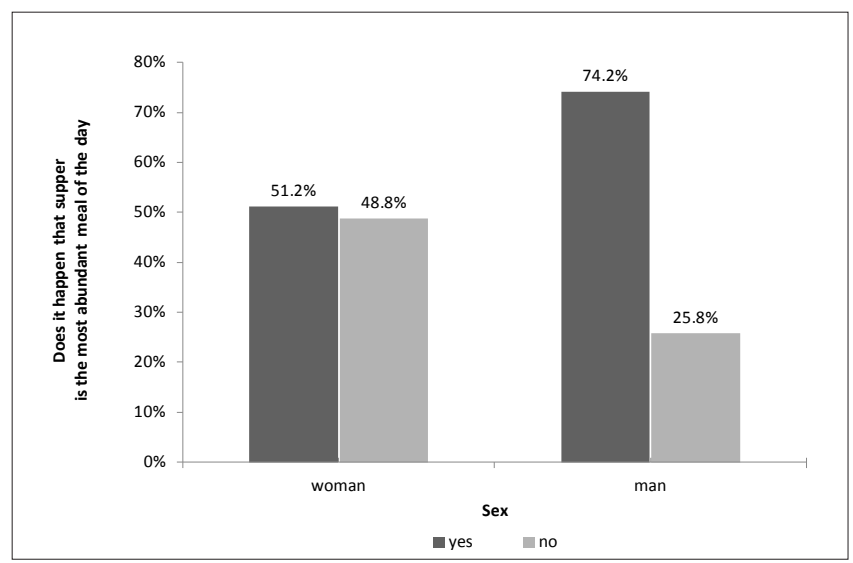

FIGURE 1. Consuming supper by the students.

of the country. A larger number of country students as compared to city students had no beef at all (Table 3 ). Poultry was consumed several times during the week by $31.9 \%$ of women and $43.3 \%$ of men. Everyday consumption of poultry was declared by a similar number of women and men (Table 3). Students living in a city $-44.1 \%$ substantially more often than those living in the country $(29.1 \%)$ ate poultry $-\mathrm{a}$ few times during the week $(\mathrm{p}<0.05)$. In every day menu poultry was more often found at city dwellers (11.9\%)menu as compared to country dwellers' menu (5.2\%).

Approximately half of country dwellers (45.5\%) and $27.1 \%$ of the city preferred consuming poultry once during the week $(p<0.05)$. Fish was consumed barely once a week by more than a half of the students $(52.8 \%)$. Fish

TABLE 3. The frequency of consumption of meat and fish and the sex of the respondents.

\begin{tabular}{|c|c|c|c|c|c|c|}
\hline \multirow{3}{*}{$\begin{array}{l}\text { Type of } \\
\text { meat/fish }\end{array}$} & \multirow{3}{*}{$\begin{array}{l}\text { Frequency of con- } \\
\text { sumption }\end{array}$} & \multicolumn{4}{|c|}{ Sex } & \multirow{3}{*}{$\mathrm{p}$} \\
\hline & & \multicolumn{2}{|c|}{ Women } & \multicolumn{2}{|c|}{ Men } & \\
\hline & & $\%$ & $\mathrm{~N}$ & $\%$ & $\mathrm{~N}$ & \\
\hline \multirow{5}{*}{ Pork } & Every day & $1.2 \%$ & 2 & $10.0 \%$ & 3 & \multirow{5}{*}{0.0001} \\
\hline & Few times a week & $19.1 \%$ & 31 & $40.0 \%$ & 12 & \\
\hline & Once a week & $33.3 \%$ & 54 & $36.7 \%$ & 11 & \\
\hline & Barely once a week & $23.5 \%$ & 38 & $13.3 \%$ & 4 & \\
\hline & Never & $22.8 \%$ & 37 & $0.0 \%$ & 0 & \\
\hline \multirow{5}{*}{ Beef } & Every day & $0.6 \%$ & 1 & $10.0 \%$ & 3 & \multirow{5}{*}{0.01} \\
\hline & Few times a week & $12.3 \%$ & 20 & $13.3 \%$ & 4 & \\
\hline & Once a week & $19.0 \%$ & 31 & $36.7 \%$ & 11 & \\
\hline & Barely once a week & $33.7 \%$ & 55 & $23.3 \%$ & 7 & \\
\hline & Never & $34.4 \%$ & 56 & $16.7 \%$ & 5 & \\
\hline \multirow{5}{*}{ Poultry } & Every day & $7.4 \%$ & 12 & $6.7 \%$ & 2 & \multirow{5}{*}{0.361} \\
\hline & Few times a week & $31.9 \%$ & 52 & $43.3 \%$ & 13 & \\
\hline & Once a week & $39.3 \%$ & 64 & $43.3 \%$ & 13 & \\
\hline & Barely once a week & $14.7 \%$ & 24 & $6.7 \%$ & 2 & \\
\hline & Never & $6.7 \%$ & 11 & $0.0 \%$ & 0 & \\
\hline \multirow{5}{*}{ Fish } & Every day & $0.0 \%$ & 0 & $0.0 \%$ & 0 & \multirow{5}{*}{0.355} \\
\hline & Few times a week & $11.0 \%$ & 18 & $3.3 \%$ & 1 & \\
\hline & Once a week & $25.8 \%$ & 42 & $36.7 \%$ & 11 & \\
\hline & Barely once a week & $52.8 \%$ & 86 & $53.3 \%$ & 16 & \\
\hline & Never & $9.2 \%$ & 15 & $3.3 \%$ & 1 & \\
\hline
\end{tabular}

was consumed once a week by $36.7 \%$ of men and $25.8 \%$ of women. A few times a week consumption of fish was declared by $11.0 \%$ of women and $3.3 \%$ of men (Table 3 ). The rural dwellers (55.2\%) more often than city dwellers (47.5\%) had fish more rarely than once a week $(p=0.5)$. Once a week consumption of fish was declared by every third city dweller $(28.8 \%)$ and country dweller $(26.9 \%)$. Every twelfth city and country dweller did not consume fish at all (8.3\%). Analysing the mistakes concerning the way of dieting, attention was focused on the fact that both the students living in the country $(85.9 \%)$, as well as in the city $(89.8 \%)$ were characterised by the habit of consuming something between meals $(p<0.5)$.

TABLE 4. Preferred type of snacks consumed by the students.

\begin{tabular}{|c|c|c|c|c|c|c|}
\hline \multirow{3}{*}{$\begin{array}{c}\text { Type } \\
\text { of snack }\end{array}$} & \multirow{3}{*}{$\begin{array}{l}\text { Declared } \\
\text { consumption }\end{array}$} & \multicolumn{4}{|c|}{ Sex } & \multirow{3}{*}{$\mathrm{p}$} \\
\hline & & \multicolumn{2}{|c|}{ Women } & \multicolumn{2}{|c|}{ Men } & \\
\hline & & $\%$ & $\mathrm{~N}$ & $\%$ & $\mathrm{~N}$ & \\
\hline \multirow{2}{*}{ Sweets } & Yes & $42.3 \%$ & 69 & $45.2 \%$ & 14 & \multirow{2}{*}{$>0.77$} \\
\hline & No & $57.7 \%$ & 94 & $54.8 \%$ & 17 & \\
\hline \multirow{2}{*}{$\begin{array}{l}\text { Salty } \\
\text { snacks }\end{array}$} & Yes & $17.2 \%$ & 28 & $19.4 \%$ & 6 & \multirow{2}{*}{$>0.5$} \\
\hline & No & $88.8 \%$ & 135 & $80.6 \%$ & 25 & \\
\hline \multirow{2}{*}{$\begin{array}{l}\text { Fresh } \\
\text { fruit }\end{array}$} & Yes & $39.9 \%$ & 65 & $9.7 \%$ & 3 & \multirow{2}{*}{$>0.001$} \\
\hline & No & $60.1 \%$ & 98 & $90.3 \%$ & 28 & \\
\hline \multirow{2}{*}{ Other } & Yes & $7.4 \%$ & 12 & $16.1 \%$ & 5 & \multirow{2}{*}{$<0.5$} \\
\hline & No & $92.6 \%$ & 151 & $83.9 \%$ & 26 & \\
\hline
\end{tabular}

Similar percentage of women (42.3\%) and men (45.2\%) consumed between meals most often sweets, i.e. bars of chocolate, cookies, teacakes, sweets and the like (Table 3). Students living in the country (47.4\%) decidedly more often than the city students $(32.2 \%)$ declared consuming sweets between meals $(p=0.05)$. Salty snacks as crisps, fingers, nuts, crackers were slightly more preferred by fewer women comparing to men (Table 3). City dwellers more often consumed salty snacks $-20.3 \%$ than country students $16.3 \%(\mathrm{p}=0.496)$. Almost fourfold more women than men consumed fresh fruit between meals. City dwellers (42.4\%) comparing to country dwellers $-31.9 \%(\mathrm{p}=0.15)$ more often declared consuming fruit as snacks. Every day definitely more women had coffee (42.3\%) comparing to $26.7 \%$ men $(\mathrm{p}=0.01)$. Also, it is worth emphasizing that definitely larger percentage of men $-40.0 \%$ towards the examined women (22.1\%) did not drink coffee at all.

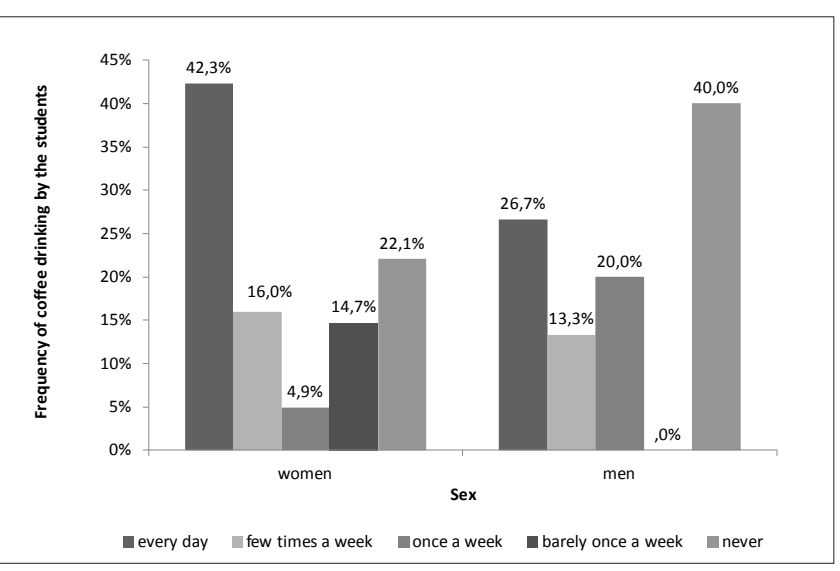

FIGURE 2. Frequency of coffee drinking by the students. 


\section{DISCUSSION}

Satisfying fundamental need of life and health of man is the a need of dieting, which is basic right, condition of living, condition of development, work output and the realtion to environment [4]. Rational dieting takes into account delivering appropriate amount of energy and essential nutritients to man to provide functioning and keeping the due body mass and the preservation of health. Experts in the field of dieting recommend consuming no less than 4-5 meals a day $[3,6]$. Such an amount of meals provides an optimum percentage distribution of the energy value within the 24 hour period. Individual meals should constitute the source of all essential nutrients which could ensure the correct course of processes of the metabolism in the body. The number of eaten meals in a day is conditioned by age, type of work, a physiological state and a standard of living. Dietary customs are conditioned by the geographical situation and the economic status. At present the style of dieting is under the significant effect of the advertisement and mass media [3].

Planning the daily diet with four meals takes into account the consumption of the first and second packed lunch, dinner and supper. The afternoon snack is an element of the schedule of consuming five meals per day. Such configuration of meals is most optimal for the human organism. Consuming scarcely one or two meals in a day causes adverse effects for the organism, constituting one of main causes of obesity [7]. Analysis of our own findings showed that $51.3 \%$ of students of the Sanok college had from four to five meals per day. Dydjow-Bendek et al., assessing the style of dieting of students at Medical University in Gdańsk achieved similar results [8]. According to findings of Bińkowska - Bury only half of students (43.6\%) of Rzeszów colleges fed themselves regularly. The largest percentage of 'irregularly dieting students' was constituted by the students of medical courses [9].

According to dietary recommendations being in force in Poland, beginning every day with breakfast is an important aspect of correct dieting [3]. Breakfast constitutes the essential meal in the daily menu. Every day should start with breakfast eaten by students in the family house in the hall of residence or in lodgings. The lack of the custom of consuming the first breakfast causes lowering of the bloodglucose level, and in consequence, reduction of productivity in learning and work. Also drinking only a cup of coffee for breakfast is a problem. Later, before the dinner the first meal is the so-called 'dry provisions' meal consisting of the bread and the cold cooked meat, in combination with tea often deprived of vegetables and fruit [7]. Students of Sanok college regarded the breakfast as the most important meal in the daily menu. Over half of the examined studying persons in Sanok had this meal every day. Achieved results correspond with the custom of regular everyday consuming the breakfast by students studying in Gdańsk and in Rzeszów $[8,9]$.

Diversifying meals in the consumption was visible in styles of consuming the dinner amongst students of Sanok and Gdańsk. In Sanok it was consumed every day by $48.3 \%$ of city dwellers and only by $27.9 \%$ of those living in the country. A similar percentage of consuming dinner every day was confirmed among the students of Rzeszów colleges by Bińkowska-Bury. The percentage of students consuming the dinner every day was definitely higher $(77.0 \%)$ in Gdańsk as comparing to Sanok college [8,9]. Dinner should deliver $30-40 \%$, not to say the half of the daily caloric requirement and contain ingredients from all food groups with maintaining the right proportions. Consuming dinner should interface with time of rest of both relaxation, establishing social contacts and cultivating correct principles and the culture of dieting. Experience shows that correct dieting of young people during the learning - studying is possible only at subsidies of the state for this purpose [10]. Dinner in the form of hot meals is most often consumed by adults in the form of "supper-dinner meal" in late afternoon. It is then a very much lavish meal, frequently causing considerable burdening of the stomach, as well as sleep disorders [7]. In our own examinations around half of students living in a city and substantially smaller group living in the country had dinner consisting of two dishes every day.

Small percentage of students in our own examinations didn't eat supper, which generally speaking, much diverged from achieved results by Bińkowska-Bury, in which only every tenth examined student didn't eat supper. Perhaps an alarming fact may be consuming supper only hour before the sleep by PWSZ students in Sanok. Nutritional standards recommend consuming supper the minimum two hours before the sleep. Almost half of examined students overlooked the time of consuming the last meal.

Following dietary recommendations is an element of the prevention of illnesses being an effect of wrong dieting. Nonobservance of principles of a well-balanced diet, exercising wrong habits in the process of the socialization all increase the risk of the appearance of disorders. Most frequent mistake as for diet is a lack of restrictions included in consuming simple carbohydrates $[3,11]$. A custom of consuming food between meals is a wrong habit of Poles, especially of sweets (cookies, sweets) and of confectionery products (of crackers, crisps, chips). The daily demand for the energy coming from carbohydrates should not exceed $50-70 \%$. Sucrose (sugar, confectionery products) can constitute the source for the $10 \%$ of the daily energy. Monosaccharides are increasing the amount of cholesterol, especially LDL (Eng. low density lipoproteins), of neutral fats and hampers maintaining the correct body mass [3]. Excessive consumption of refined carbohydrates (sugar, sweets, white bread, cookies), can cause the so-called 'empty calories' and may result in vitamin, mineral deficiency, especially of iron and calcium $[7,11,12]$.

In our own examinations over half of students consumed sweets between main meals. Custom of frequent nibbling at sweets between main meals by students of Sanok is comparable to results obtained by Dydjow-Bendek et al., according to whom $-67.0 \%$ of students of Medical University in Gdańsk consumed sweets several times during the week. Over one third of students of Rzeszów colleges didn't apply restrictions in consuming the sugar and the sweets [8]. Higher percentage of nibbling between meals was proved by Wołos in her examinations amongst students of Lublin colleges [13].

Specialists in dietetics and related fields emphasize that dietary mistakes are a relevant problem of persons after 20th 
year of life(the findings confirm that as well). PiecewiczSzczęsna, examining a lifestyle of residents of Sanok district, pointed at dietetic mistakes as the main factor of the threat to health, and among them excessive consumption of simple carbohydrates [14]. Excessive consumption of such sugars was noticed by experts preparing the National Program of the Health (NPZ), proposing in 2007-2015 limiting of consuming of carbohydrates in the diet [15]. Fruit and vegetables have alkalizing properties and are the source of vitamins and mineral salts. They should be added to every meal, best in the raw or cooked form [7].

The small percentage of PWSZ students consumed fresh fruit and vegetables between meals. It is necessary to consume meat and its products only 2-3 times during the week. Additional source of proteins should be fish and leguminous plants (pulses) [7]. Meat, cold cooked meats, poultry and fish are important sources of animal protein, but also fat which has the small nutritional value. Therefore limiting the consumption of meat, especially the red one, is important. Consuming the lean fowl (chicken, hen, turkey) and fish is recommended, especially of sea fish which is good source of iodine and fatty acids preventing atherosclerosis [4]. The meat additionally acidifies the organism [7]. The PUFA fats constitute energy sources and source of soluble vitamins, performing the structural function in the body, being an element of cells, tissues, bodily fluids. The source of polyunsaturated fatty acids recommended for the consumption (PUFAs) are oils of the animal origin, but especially saltwater fish. PUFAs regulate functioning of the cardiovascular system, secretions of digestive juices and influence aggregation of blood platelets. They also have an ability to lower cholesterol and lipids in blood, preventing blood clots and atherosclerosis. Delivered fats with the food have a significant effect for the level of the blood-cholesterol $[16,17]$. In our own examinations it was showed that meat had turned out to be the very popular product in the diet. Over half $(67.0 \%)$ of students ate cold cooked meat for breakfast. For dinner, the students of Sanok, declared most often consuming the poultry. The pork for was enjoyed for dinner few times during the week by the $20.0 \%$ of women and the half men. Students of Sanok college had most rarely beef for dinner.

Rational dieting has an indisputable influence on supporting the sound health. Observing established norms depending on the age, sex, physical activity and physiological state is a fundamental rule of dieting. It is exquisitely difficult to accomplish and often not-followed, causing negative health effects in consequence. Therefore, with a purpose of the elimination of adverse consequences of wrong dieting, and hence the assurance of correct due body mass, principles of dieting for all sorts groups of the population were developed $[5,6]$. Correct dieting consists in satisfying the demand of the organism for the energy and nutrients, but also their optimum distribution in a day and in every meal. Necessary ingredients provided in individual meals ensure the correct course of basic metabolic processes, allowing to avoid disorders. Abnormal plan of meals leads to reducing the resistance (especially to the stress) and of psychophysical function of the organism. The excess in the consumption is a main cause of obesity and supports the development of degenerative, cardiovascular and cancerous diseases. The development of diseases most often takes place after long practising of wrong consuming habits, which, as for Poles include the abnormal distribution and the excess of caloric value of meals [7].

Other negative irregularities in the way of dieting are: consuming meals in a hurry, standing, in not-favourable housing conditions. Consuming cold meals or improperly prepared and served is another sin. Cold meals are tasteless, adversely affect functioning of the digestive tract, and the hot ones cause inflammatory conditions within the digestive tract, including cancers. Daily distribution of meals is made conditional to the region of the world and it is possible to distinguish consuming habits in Anglo-Saxon countries, associated with consuming the lavish meal in the evening, and Mediterranean being marked by big consumption of vegetables and fruit. In final years in Central Europe, including Poland, a popular custom of consuming the dinner in late afternoon hours got well rooted, which is a wrong and disadvantageous phenomenon for the health [7].

\section{CONCLUSIONS}

The pro-health behaviour of the students comprises: regular consumption of the breakfast and regarding this meal as most important in the daily menu and consuming per day 4-5 meals daily by over the half of the examined. One should aspire to eliminating anti-health behaviour, such as consuming food between meals, of especially sweets, exaggerated consuming of the pork and frequent drinking of coffee. Acquaintance of mistakes in dieting at students allows for correcting disadvantageous habits by taking proper preventive action.

\section{REFERENCES}

1. Przewoźniak L. Społeczne i ekonomiczne uwarunkowania zdrowia. In: A. Czupryna, S. Poździoch, A. Ryś, WC. Włodarczyk (ed). Zdrowie publiczne. Kraków: UJ; 2000. p. 71-98.

2. Gawęcki J. Żywność i żywienie a zdrowie. In: J. Gawęcki, W. Roszkowski. Żywienie człowieka a zdrowie publiczne. Warszawa: PWN; 2009. p.37-55.

3. Gertig H, Przysławski W. Bromatologia. Zarys nauki o żywności i żywieniu. Warszawa: PZWL;2006.

4. Rudnicka A. Zasady żywienia różnych grup ludności. In: H. Ciborowska, A. Rudnicka (ed). Dietetyka. Żywienie zdrowego i chorego człowieka. Warszawa: PZWL;2007. p. 181-93.

5. Rudnicka A. Sytuacja żywnościowa i żywieniowa na świecie i w Polsce. In: H. Ciborowska, A. Rudnicka (ed). Dietetyka. Żywienie zdrowego i chorego człowieka. Warszawa: PZWL;2007. p. 13-18.

6. Ciborowska H. Składniki odżywcze w żywieniu. In: H. Ciborowska, A. Rudnicka (ed). Dietetyka. Żywienie zdrowego i chorego człowieka. Warszawa: PZWL;2007. p. 32-180.

7. Ziemlański Ś. Żywienie osób dorosłych zuwzględnieniem zróżnicowanej aktywności fizycznej. In: J. Hasik, J. Gawęcki (ed). Żywienie człowieka zdrowego i chorego. Warszawa: PWN;2000. p. 32-110.

8. Dydjow-Bendek D, Ejsmont J. Sposób żywienia a ryzyko wystąpienia chorób nowotworowych. Prob Hig Epidemiol. 2010;91(4):618-22.

9. Bińkowska-Bury M. Zachowania zdrowotne młodzieży akademickiej. Rzeszów: Wydawnictwo Uniwersytetu Rzeszowskiego; 2009.

10. Szotowa W. Praktyczne wskazówki do prawidłowego żywienia w różnych okresach życia. In: J. Hasik, J. Gawęcki (ed). Żywienie człowieka zdrowego i chorego Warszawa: PWN;2000. p. 9-31.

11. Nowicka G, Paneczko-Kresowska B. Węglowodany. In: M. Jarosz, B. Bułchak-Jachymczyk (ed). Normy żywienia człowieka. Podstawy 
prewencji otyłości i chorób niezakaźnych. Warszawa: PZWL;2008. p. $137-59$.

12. Ziemlański Ś. Zapotrzebowanie człowieka na węglowodany. In: Ś. Ziemlański (ed). Normy żywienia człowieka. Fizjologiczne podstawy. Warszawa: PZWL;2001. p. 58-77.

13. Wołos J, Tarach JS, Klatka M. Występowanie otyłości i środowiskowych czynników ryzyka miażdżycy w grupie studentów uczelni wyższych w Lublinie. Endokrynol Otył Zab Przem Mat. 2009;5(2):66-72.

14. Piecewicz-Szczęsna H. Wybrane czynniki stylu życia rodzin mieszkańców Sanoka i przyległych gmin. Probl Hig Epidemiol. 2008;98(3):373-7

15. Narodowy Program Zdrowia z dnia 30. 10. 2010., www.mz.gov.pl.

16. Ziemlański Ś. Zapotrzebowanie człowieka na tłuszcze. In: Ś. Ziemlański (ed). Normy żywienia człowieka. Fizjologiczne podstawy. Warszawa: PZWL;2001. p. 78-114.

17. Szponar L, Mojska H, Ołtarzewski MG. Tłuszcze. In: M. Jarosz, B. Bułchak-Jachymczyk (ed). Normy żywienia człowieka. Podstawy prewencji otyłości i chorób niezakaźnych. Warszawa: PZWL;2008. p. 91-129.

\section{Informacje o Autorce}

Mgr Ewa Smoleń - asystent, Zakład Pielęgniarstwa, Instytut Medyczny, Państwowa Wyższa Szkoła Zawodowa im. Jana Grodka w Sanoku.

\section{Corresponding Author}

Ewa Smoleń

ul.Mickiewicza 21,

38-500 Sanok

tel: 667-249-796

E-mail: ewasmolen@op.pl 